Article

\title{
Comparison of Acoustic to Optical Backscatter Continuous Measurements of Suspended Sediment Concentrations and Their Characterization in an Agriculturally Impacted River
}

\author{
Zacharie Sirabahenda ${ }^{1, *}{ }^{\mathbb{D}}$, André St-Hilaire $\left.{ }^{1} \mathbb{(}\right)$, Simon C. Courtenay ${ }^{2}$ and \\ Michael R. van den Heuvel ${ }^{3}$ (D) \\ 1 Canadian Rivers Institute, INRS-ETE, 490 Rue de la Couronne, Québec City, QC G1K 9A9, Canada; \\ Andre.St-Hilaire@ete.inrs.ca \\ 2 Canadian Rivers Institute, School of Environment, Resources and Sustainability, University of Waterloo, \\ 200 University Avenue West, Waterloo, ON N2L 3G1, Canada; scourten@connect.uwaterloo.ca \\ 3 Canadian Rivers Institute, Department of Biology, University of Prince Edward Island, \\ 550 University Avenue, Charlottetown, PEI C1A 4P3, Canada; mheuvel@upei.ca \\ * Correspondence: zacharie.sirabahenda@ete.inrs.ca
}

Received: 19 March 2019; Accepted: 8 May 2019; Published: 10 May 2019

\begin{abstract}
The increased soil loss in an agricultural watershed raises challengers for river water quality and a reliable automated monitoring for suspended sediment concentrations (SSC) is crucial to evaluate sediment budgets variation in systems. The aims of this study were (1) to test if an acoustic doppler current profiler (ADCP) would give similar results to turbidity probe measurements as a high frequency monitoring tool for suspended sediment; and (2) to analyze the relationship between sediment drivers and SSC in a typical agricultural drainage basin. The acoustic and optical backscatter sensors were used to collect SSC data during the ice-free seasons of four consecutive years in the Dunk River (PEI, Canada). The slopes of the relationships between the two SSC indirect measurements were not significantly different than 1 . Correlations between SSC and hydro-meteorological variables showed that the high SSC values were more associated with the streamflow and water velocity than precipitation. This study highlighted the great potential of ADCP for the continuous monitoring of suspended sediment in an agricultural watershed. For summer periods the prevalence of clockwise hysteresis $\left(74.1 \%\right.$ of measured rainstorm events with SSC $>25 \mathrm{mg} \mathrm{L}^{-1}$ ) appeared related to rainstorm behaviors.
\end{abstract}

Keywords: turbidity; ADCP; sediment dynamic; agricultural watershed

\section{Introduction}

River water quality and ecosystem integrity are often threatened by human activities [1,2]. Rivers within agricultural watersheds can be impacted by erosion that leads to a high level of turbidity and an increase of the sediment-associated pollutant load originating from the drainage basin. This in turn, may result in damage to aquatic flora and fauna [3,4]. The increased soil loss rate in farm fields raises challenges for implementing soil conservation techniques [5,6]. Water resource protection strategies need to include in situ measurement protocols for detecting changes in suspended sediment concentration (SSC) in order to evaluate remedial actions.

A cost-effective and reliable automated sampling or monitoring strategy for SSC is essential to develop sediment budgets in systems. Optical backscatter sensors (OBS), and more recently acoustic backscatter sensors, are indirect SSC monitoring techniques suitable for continual monitoring that 
is essential for a highly temporally variable such as SSC [7-9]. The technologies of both types of instrument have improved markedly recently and they have been successfully applied to quantifying the suspended sediment transports in many fluvial environments [10-14]. The more recently introduced ADCPs have the advantage of being able to collect vertical profiling of sediment concentration and water velocity variation as compared to OBS. Furthermore, the conversion of backscatter data to SSC is complicated due to the site-specific variability in sediment physical properties $[15,16]$. Co-deployment of optical and acoustic backscatter sensors is one option that allows for partial validation of site-specific calibration [17-20].

Investigations over recent decades show an increasing interest in links between the drivers of suspended sediment transport in rivers and the uncertainties related to their spatial and temporal variability [21-23]. Hydro-climatic factors, in interaction with catchment characteristics, have been identified as the dominant drivers for suspended sediment loading over many time scales [24-26]. However, sediment budget variation was found to be strongly dependent on local conditions and there is still need of a better understanding of the functional relationships between variables that most affect sediment dynamics. Hence, a systematic assessment of the degree of correlation and hysteresis patterns between hydro-climatic factors and SSC provides valuable insights for development of sediment estimation tools within rivers $[27,28]$.

Environmental stakeholders in Prince Edward Island (PEI) recognize the increasing degradation of the water quality in estuaries and coastal waters. Sediments from intense agricultural activities are among the major sources of pollution [16,29]. The soils in PEI are extremely sensitive to water erosion and the soil losses have been reported as a major long-term environmental and economic challenge for the province [30,31]. The Dunk River (PEI, Canada) has historically experienced fish kills linked to the use of pesticides that can bind to soil and/or be transported by erosion processes on its highly agricultural watershed during summer rainstorms [32,33]. Degradation of its water quality through high sediment loads caused by an annual mean soil loss estimated at 10 tonnes ha ${ }^{-1}$ has been reported for over a decade [1,34]. Hence, continuously monitoring suspended sediment yield, with adequate techniques to acquire representative data, is necessary to support water resources managers and farm owners in their efforts to address the water quality issues in the Dunk River. Furthermore, a descriptive analysis focusing on the interdependence between suspended sediment fluxes and other hydro-meteorological variables may prove instructive in the development of strategies to protect and preserve its water resources.

The hypothesis of this study was that the use of ADCP would give similar results to turbidity probe measurements as a high frequency monitoring tool for suspended sediment in an agricultural river basin. The hypothesis was examined through continuously monitoring suspended sediment yield using both technologies in the Dunk River. Furthermore, as a second objective, this study sought to elucidate descriptive relationships between suspended sediment fluxes and hydro-meteorological variables. Specifically, the degree of correlation between SSC and the hydro-meteorological variables was quantified using ADCP backscatter data. The SSC temporal variability was also investigated by analyzing the hysteresis loops between streamflow and SSC for rainstorm events for different years.

\section{Materials and Methods}

\subsection{Site Description and Instrument Setup}

The Dunk River is situated in the central portion of Prince Edward Island (Canada) and flows into the Bedeque Bay that empties into the Northumberland Strait in the Southern Gulf of St. Lawrence (Figure 1). Suspended sediment was measured within the Dunk River at a monitoring station $\left(46^{\circ} 20^{\prime} 5^{\prime \prime} \mathrm{N}, 63^{\circ} 39^{\prime} 46^{\prime \prime} \mathrm{W}\right)$ with an upstream watershed surface area of $140.6 \mathrm{~km}^{2}$. The studied watershed area is dominated by agriculture (66.1\%) while the forest covers an area of $25.1 \%$. The topographic relief is largely of moderately undulating plains with low slopes [1]. The Dunk watershed soils are geologically derived from sedimentary rocks known as redbeds and formed during 
the Stephanian-late Early Permian period [35]. The two dominant soil types for the study area are the Charlottetown soil series (mainly well drained) and the Albery soil series (moderately drained) occupying, respectively, $74.4 \%$ and $17.7 \%$ of the total surface area.

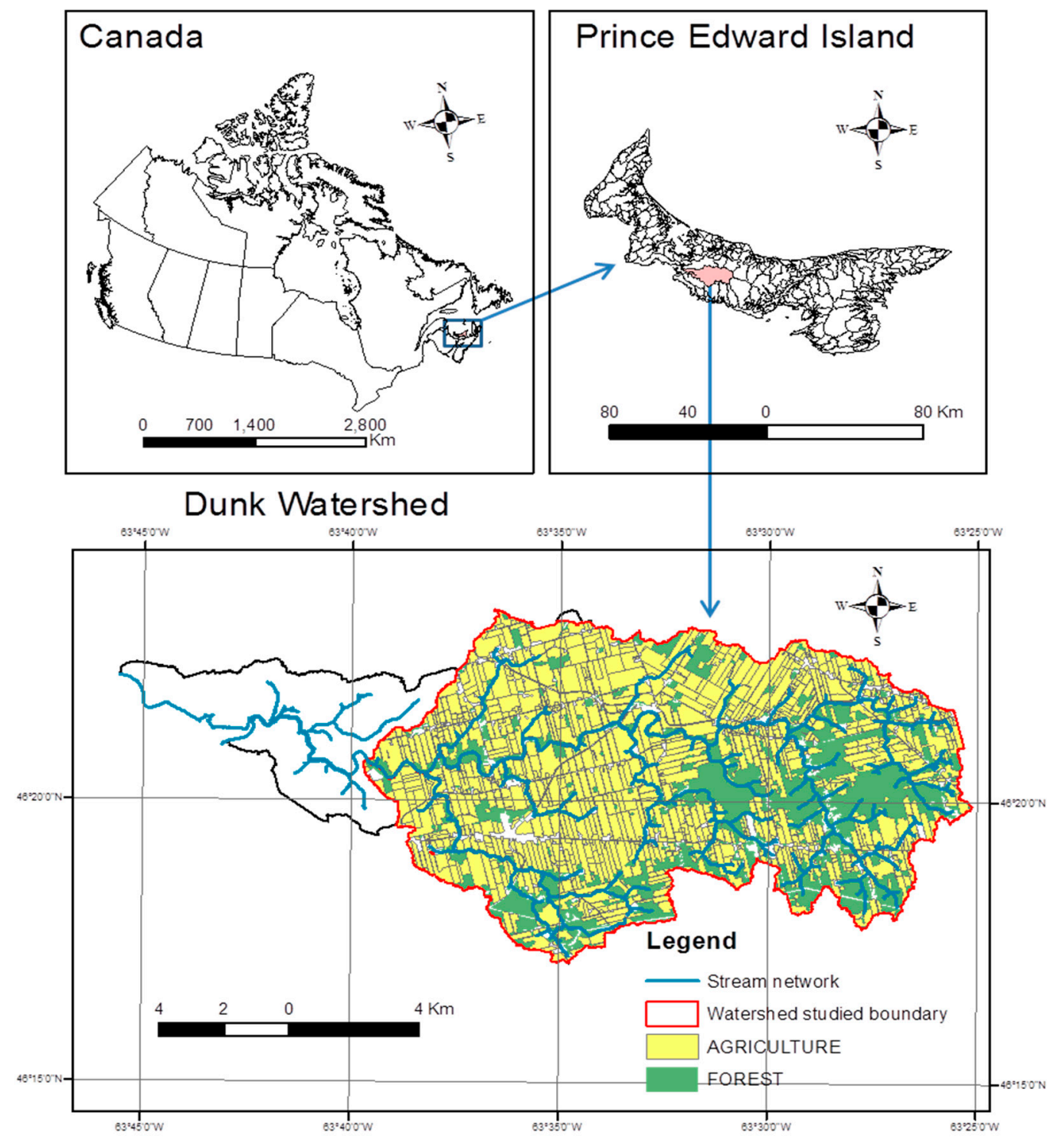

Figure 1. Dunk River Watershed location.

SSC data were collected using acoustic and optical instruments during monitoring campaigns in May-August 2013, and from June until October for the years 2014-2016. A Sentinel V-ADCP (1000 KHz with four beams) from Teledyne RD Instruments (Poway, CA, USA) was deployed on the river bed (upward-looking) for acoustic backscatter monitoring (minimum depth above the ADCP: $0.95 \mathrm{~m}$ ). It was set up to collect velocity and acoustic backscatter in $1 \mathrm{~min}$ bursts (60 pings) every $30 \mathrm{~min}$. The bin size and the blank distance were configured to $0.30 \mathrm{~m}$ and $0.30 \mathrm{~m}$, respectively. To avoid any errors due to magnetic field distortions, the compass calibration was first conducted at the monitoring station location as per manufacturer's instructions.

For optical backscatter sampling, a YSI 6136 turbidity probe from Teledyne RD Instruments (Poway, CA, USA) was installed near the Sentinel V for sampling turbidity data in nephelometric turbidity units (NTU) with a recording frequency of $30 \mathrm{~min}$ during the same period. The turbidity measured by the YSI sensor are based on the absorption of infrared radiation emitted by the sensor and backscattered by suspended sediment through the water body [36]. YSI-certified polymer-based 
standards were used for primary calibration and the unit associated with turbidity readings was NTU. For the proper device maintenance and to avoid bio-fouling effects, a regular daily automatic cleaning was set up and an instrument calibration was completed every year.

\subsection{Conversion of the Acoustic and Optical Backscatters Data to SSC}

The relationship between the turbidity measurements in NTU and SSC in $\mathrm{mg} \mathrm{L}^{-1}$ was determined using sediment concentrations of the mixtures of in situ water and local sediment as a function of their correspondent recorded turbidity. Local water and sediments (wet sieved using a $63-\mu \mathrm{m}$ sieve to retain only the fine particles that are most likely to be suspended in the water column) were mixed at different concentrations in a $40 \mathrm{~L}$ container and mixed constantly while the turbidity meter was immersed in the solution. This protocol was repeated many times to cover the largest possible range of SSC values [37]. The sediment concentrations of the grab samples were calculated after filtering, drying, and weighing in the laboratory. Thus, data were fitted with a non-linear function (Equation (1)) using the Levenberg-Marquardt algorithm, using the nlinfit function in Matlab software developed by The Mathworks, Inc. (Natick, MA, USA) [38]:

$$
\mathrm{SSC}=a_{1} \times(\text { Turbidity })^{b_{1}}
$$

where SSC and Turbidity are expressed in $\mathrm{mg} \mathrm{L}^{-1}$ and in NTU, respectively; $a_{1}$ and $b_{1}$ are coefficients to be estimated.

Backscatter data recorded by the Sentinel V-ADCP were calibrated against concentration of sediment in collocated grab samples. To cover a wide range of sediment concentrations encountered in river, solutions with different concentrations were pumped gradually upstream of the Sentinel V and were allowed to flow downstream. Grab samples associated with different SSC were collected above the ADCP concomitantly with V-ADCP measurements. For the conversion of the received echo intensity to SSC, the exponential form of the sonar equation [39] was used:

$$
10 \log _{10}(\mathrm{SSC})=a_{2}+b_{2} I_{d b}
$$

where $a_{2}$ and $b_{2}$ are parameters representing the characteristics of the instrument obtained by calibration using a linear regression analysis; $I_{d b}$ is the relative acoustic backscatter and expressed based on the equation proposed by Deinnes [40]:

$$
\begin{gathered}
I_{d b}=C+10 \log _{10}\left((T+273.16) R^{2}\right)-10 \log _{10}\left(L_{t}\right)-10 \log _{10}\left(P_{w}\right)+2 \alpha R+K_{c}\left(E-E_{r}\right) \\
R=r+\frac{D}{4}
\end{gathered}
$$

where $C$ is a constant combining several parameters specific to each instrument, $T$ is the temperature measured at the transducer $\left({ }^{\circ} \mathrm{C}\right) ; R$ is the slant distance $(\mathrm{m}) ; r$ is the distance between the surface of the sentinel V-ADCP emitters and the midpoint of the bin $(\mathrm{m}) ; D$ is the width of the bin $(\mathrm{m}) ; L_{t}$ is the transmit pulse length $(\mathrm{m}) ; P_{w}$ is the acoustic transmit power level $(\mathrm{w}) ; \alpha$ represent the absorption coefficient combining the sound absorption factor due to water $\alpha_{\mathrm{w}}$ and the sound absorption by particles $\alpha_{\mathrm{S}}$ due to properties of sediment; $E$ is the received signal strength indicator (RSSI) amplitude for each bin recorded by the Sentinel V-ADCP (counts); $E_{r}$ is the RSSI amplitude in the absence of noise (counts) and it is calibrated to be 40 counts for the Sentinel V-ADCP [41]; $K_{c}$ is a conversion factor for counts to decibels and it calibrated to be $0.40 \mathrm{db}$ count $^{-1}$ for the Sentinel V-ADCP [41].

Inter-annual correspondence of SSC estimated by acoustic backscatter versus optical backscatter was quantified using four commonly used index statistics [42]: the Nash-Sutcliffe efficiency (NSE), the Coefficient of determination $\left(\mathrm{R}^{2}\right)$, the root mean square error (RMSE) and the percent bias (PBIAS). The NSE is a standardized statistic that indicates the relative magnitude of the residual variance compared to the measured data variance [43]. The NSE is calculated with Equation (5) and can range 
from $-\infty$ to 1 . The values of NSE close to 1 indicate a high level of performance for a model. The RMSE indicates the error in the units of the variable of interest. The $\mathrm{R}^{2}$ describes the degree of collinearity between two variables data while the PBIAS measures the average absolute difference between the two methods [44]. The PBIAS is computed as shown in Equation (6) and a good model is characterized by the low values of PBIAS. The $\mathrm{R}^{2}$ is similar to NSE and its values ranges between 0 (the model explains no variance) and 1 (perfect linear relationship between model and measurements). The RMSE indicates the error in the units of the variable of interest. It is calculated with Equation (7) and values close to 0 indicate a good agreement between observed values and predicted values:

$$
\begin{array}{r}
\text { NSE }=1-\frac{\sum_{i=1}^{n}\left(X_{i}-Y_{i}\right)^{2}}{\sum_{i=1}^{n}\left(X_{i}-\bar{X}_{i}\right)^{2}} \\
\text { PBIAS }=\frac{\sum_{i=1}^{n}\left(X_{i}-Y_{i}\right) \times 100}{\sum_{i=1}^{n} X_{i}} \\
\text { RMSE }=\sqrt{\frac{\sum_{i=1}^{n}\left(X_{i}-Y_{i}\right)^{2}}{n}}
\end{array}
$$

where $X_{i}$ and $\bar{X}_{i}$ are, respectively, the observed data and their average, $n$ is the number of observations and $Y_{i}$ refers to the simulated data by a model.

\subsection{Characterization of Sediment Temporal Variation}

The SSCs from acoustic backscatter data were used to characterize the catchment's sediment dynamic in relation to the hydro-climatic factors precipitation, streamflow and water velocity. The daily precipitation data for Elmwood and New Glasgow stations (http://climate.weather.gc.ca) and daily water discharges for Dunk River at Wall Road station (https://wateroffice.ec.gc.ca) operated by Environment and Climate Change Canada were used. Its interannual average discharge is $2.55 \mathrm{~m}^{3} \mathrm{~s}^{-1}$ while the highest and lowest daily averages are respectively equal to $0.212 \mathrm{~m}^{3} \mathrm{~s}^{-1}$ and $84.7 \mathrm{~m}^{3} \mathrm{~s}^{-1}$. The Climate Normals (1981-2010) indicate that the total annual precipitation is on average $1257.9 \mathrm{~mm}$ ( $944.3 \mathrm{~mm}$ for rainfall and $313.6 \mathrm{~mm}$ for snow). The extreme daily total rainfall was $85.6 \mathrm{~mm}$ and the maximum number of days with rainfall $\geq 10 \mathrm{~mm}$ was 29.7 for the New Glasgow station.

The two most commonly used correlation coefficients (Pearson coefficient and Spearman coefficient [45]) were retained to see how well the variables related. Those correlation measurements between data sets were chosen because linear and non-linear relationships are both possible between hydro-climatic factors and SSC. Pearson's r correlation is used to measure the degree of the relationship between linearly related variables. Spearman's rank correlation is a non-parametric test that is used to assess the strength of the monotonic association between two variables [46]. Hence, the sensitivity analysis was made by calculating those indices of correlation for four subsets data: SSC $>25 \mathrm{mg} \mathrm{L}^{-1}$, SSC $>15 \mathrm{mg} \mathrm{L}^{-1}, \mathrm{SSC}>10 \mathrm{mg} \mathrm{L}^{-1}$ and SSC $>0 \mathrm{mg} \mathrm{L}^{-1}$. The temporal sediment loading patterns were explored by quantifying of the number of rainfall events displaying clockwise versus anti-clockwise hysteresis loops between SSC and streamflow.

\section{Results}

\subsection{Indirect Suspended Sediment Measurements}

For the OBS, the non-linear relationship between the SSC in $\mathrm{mg} \mathrm{L}^{-1}$ as a function of the turbidity in NTU (i.e., the calibration curve) is presented in Figure 2 (NSE and $\mathrm{R}^{2}=0.96$ and 0.95 , respectively). Figure 3 shows the suspended sediment calibration curve for the ADCP that resulted from the linear regression analysis $\left(R^{2}=0.90\right.$ with $p<0.001$ for $10 \log _{10}$ (SSC) as a function of intensity of echo backscatter). 


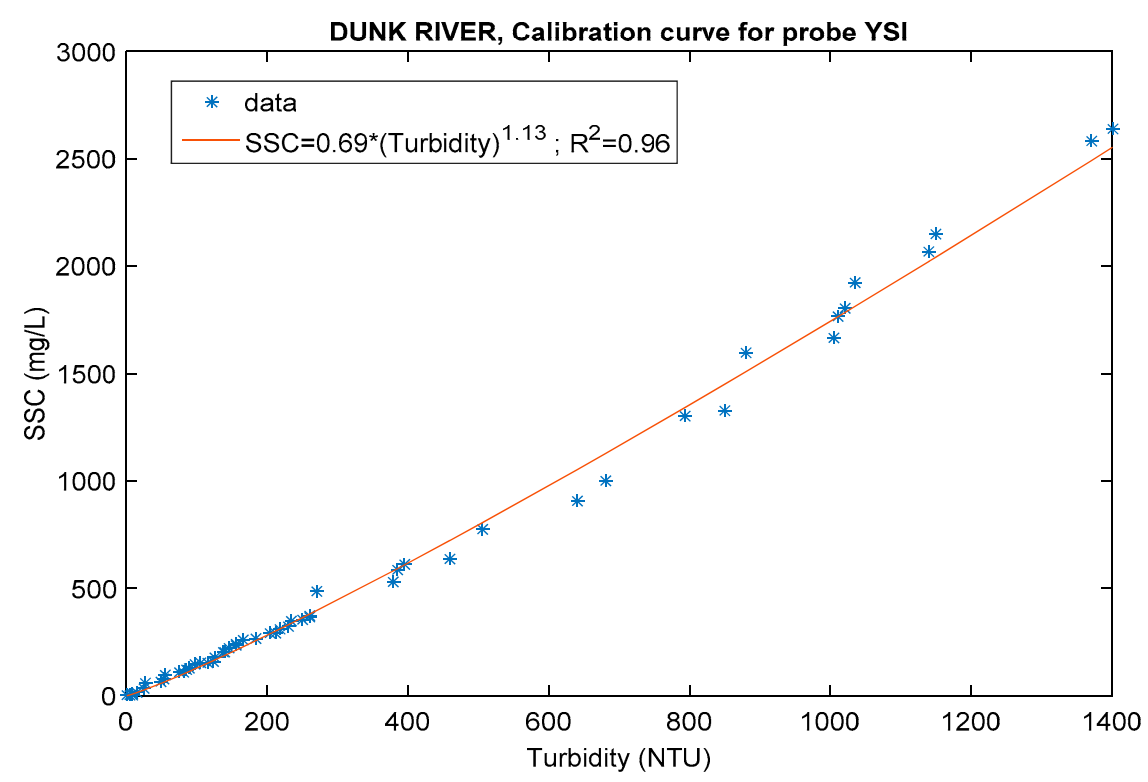

Figure 2. Suspended sediment calibration curve for a turbidity probe YSI 6136.

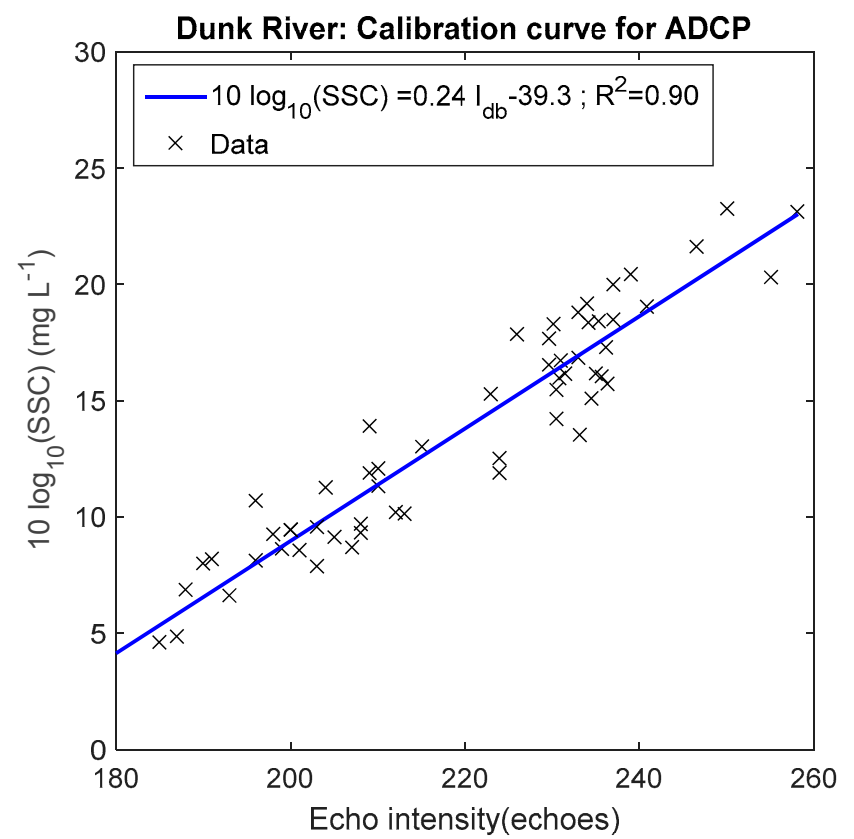

Figure 3. Suspended sediment calibration curve for the Sentinel V-ADCP.

The slope of the relationship between SSC as determined by ADCP vs. that determined using turbidity was $0.9,0.87,0.85$, and 0.87 for the four years examined. While this indicates that the ADCP produced slightly lower values, these slopes were not significantly different than 1 (Table 1, Figure 4). Despite a significant agreement between the two measurement approaches, the acoustic method provided generally lower values than optical method for high sediment concentrations (Figure 4). 
Table 1. Statistics for acoustic backscattered versus optical backscattered data.

\begin{tabular}{ccccccc}
\hline Annual Period & $\mathbf{n}$ & $\mathbf{N S E}$ & $\mathbf{R}^{\mathbf{2}}$ & $\boldsymbol{p}$ & $\mathbf{R M S E}$ & PBIAS \\
\cline { 2 - 7 } & (Days) & & & & $\mathbf{( \mathbf { m g ~ L } ^ { - 1 } )}$ & $\mathbf{( \% )}$ \\
\hline $\begin{array}{c}\text { 17 May-27 to } \\
\text { August 2013 }\end{array}$ & 103 & 0.96 & 0.98 & $<0.001$ & 5.1 & -9.6 \\
$\begin{array}{c}\text { 20 June-31 to } \\
\text { October 2014 }\end{array}$ & 144 & 0.93 & 0.96 & $<0.001$ & 11.7 & -18.8 \\
$\begin{array}{c}\text { 24 June-28 to } \\
\text { October 2015 }\end{array}$ & 127 & 0.95 & 0.98 & $<0.001$ & 7.3 & -8.8 \\
$\begin{array}{c}\text { 25 June-12 to } \\
\text { October 2016 }\end{array}$ & 110 & 0.94 & 0.96 & $<0.001$ & 8.7 & -9.7 \\
\hline
\end{tabular}
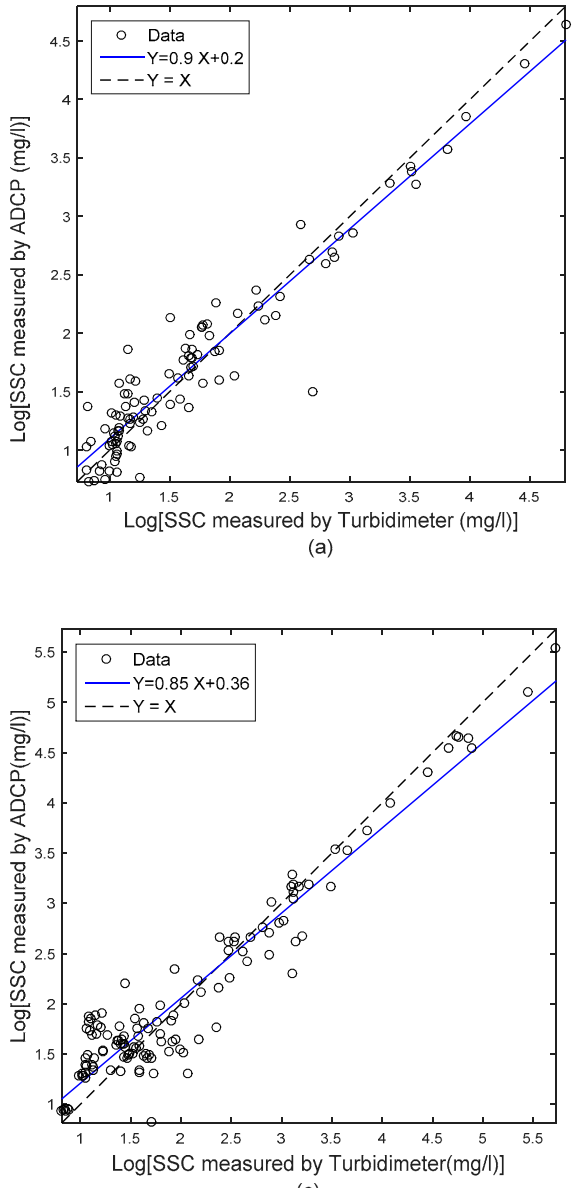
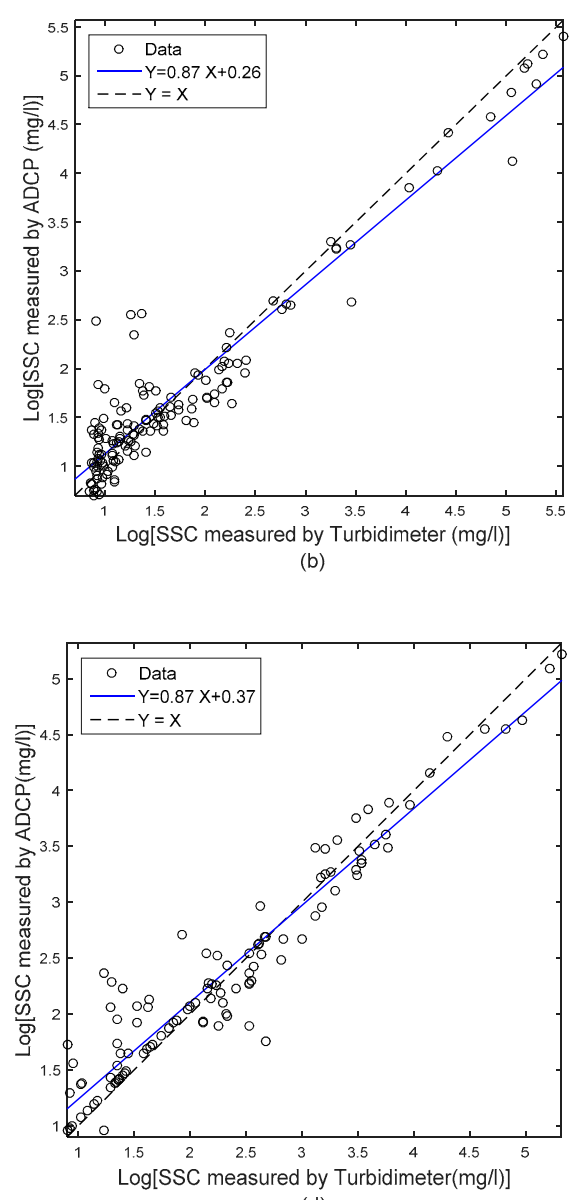

Figure 4. Daily averaged SSC measured by the Sentinel V and YSI probe for summers of 2013 (a), 2014 (b), 2015 (c), and 2016 (d).

\subsection{Sediment Temporal Variation}

The Spearman's rank correlation coefficient and the Pearson's product moment correlation coefficient were calculated successively for SSC higher than $0 \mathrm{mg} \mathrm{L}^{-1}, 10 \mathrm{mg} \mathrm{L}^{-1}, 15 \mathrm{mg} \mathrm{L}^{-1}$, and $25 \mathrm{mg} \mathrm{L}^{-1}$. Table 2 shows the result of those indices of correlation (only for $p<0.05 \%$ ) for different threshold of SSC during the four studied years. The negative values in Table 2 mean that the values of the first variable increase when the values of the second variable are decreasing. 
Table 2. Significant correlation $(p<0.05 \%)$ for Spearman (Rho) and Pearson (r).

\begin{tabular}{|c|c|c|c|c|c|c|c|}
\hline \multirow{2}{*}{\multicolumn{2}{|c|}{ Threshold of SSC }} & \multicolumn{2}{|c|}{ SSC-Flow } & \multicolumn{2}{|c|}{ SSC-Precipitation } & \multicolumn{2}{|c|}{ SSC_Velocity } \\
\hline & & Rho & $\mathbf{r}$ & Rho & $\mathbf{r}$ & Rho & $\mathbf{r}$ \\
\hline \multirow{4}{*}{$\mathrm{SSC}>0 \mathrm{mg} \mathrm{L}^{-1}$} & 2013 & 0.58 & 0.49 & 0.33 & 0.23 & 0.60 & 0.54 \\
\hline & 2014 & 0.30 & 0.30 & 0.44 & 0.33 & 0.23 & 0.26 \\
\hline & 2015 & 0.39 & 0.17 & 0.46 & 0.62 & & \\
\hline & 2016 & 0.26 & 0.34 & 0.43 & 0.41 & 0.23 & 0.21 \\
\hline \multirow{4}{*}{$\mathrm{SSC}>10 \mathrm{mg} \mathrm{L}^{-1}$} & 2013 & 0.34 & 0.28 & 0.29 & 0.25 & 0.40 & 0.43 \\
\hline & 2014 & 0.22 & 0.21 & -0.41 & -0.35 & & 0.29 \\
\hline & 2015 & 0.20 & 0.25 & 0.43 & 0.29 & 0.23 & 0.15 \\
\hline & 2016 & 0.23 & 0.30 & 0.43 & & 0.28 & 0.35 \\
\hline \multirow{4}{*}{$\mathrm{SSC}>15 \mathrm{mg} \mathrm{L}^{-1}$} & 2013 & 0.45 & 0.30 & 0.34 & 0.37 & 0.49 & 0.52 \\
\hline & 2014 & 0.34 & 0.27 & -0.33 & 0.21 & 0.40 & 0.37 \\
\hline & 2015 & 0.35 & 0.31 & 0.58 & 0.45 & 0.39 & 0.40 \\
\hline & 2016 & 0.27 & 0.30 & 0.31 & 0.36 & 0.38 & 0.45 \\
\hline \multirow{4}{*}{$\mathrm{SSC}>25 \mathrm{mg} \mathrm{L}^{-1}$} & 2013 & 0.51 & 0.54 & 0.21 & & 0.61 & 0.56 \\
\hline & 2014 & 0.46 & 0.31 & -0.17 & & 0.40 & 0.34 \\
\hline & 2015 & 0.44 & 0.19 & 0.41 & 0.55 & 0.49 & 0.36 \\
\hline & 2016 & 0.41 & 0.38 & 0.21 & 0.37 & 0.49 & 0.48 \\
\hline
\end{tabular}

The indices of correlation were moderately weak for precipitation and streamflow and showed that there were neither high significant linear relationships nor high significant monotonic function with the SSC. For high SSC (>25 mg L $\left.\mathrm{m}^{-1}\right)$, the indices of correlation were relatively improved for the streamflow and the water velocity. The hysteresis patterns between SSC and water discharge for events with SSC $>25 \mathrm{mg} \mathrm{L}^{-1}$ were analyzed graphically and an example from each year is shown in Figure 5. Over all monitoring campaign periods we collected a total of 27 events of which 20 events $(74.1 \%)$ show clockwise hysteresis loops, four events (14.8\%) had anti-clockwise hysteresis loops and three events $(11.1 \%)$ were mixed-shaped loops. This result highlighted that the pattern of SSC-discharge relationship for Dunk River is dominated by clockwise hysteresis loops.

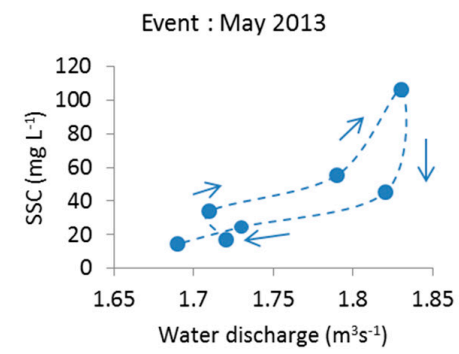

(a)

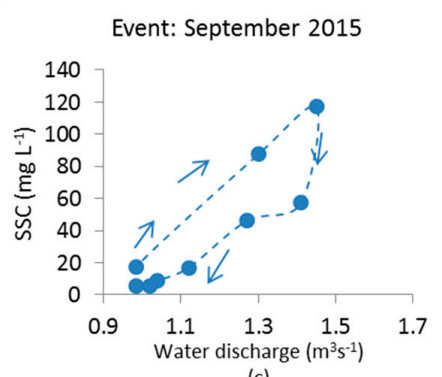

(c)

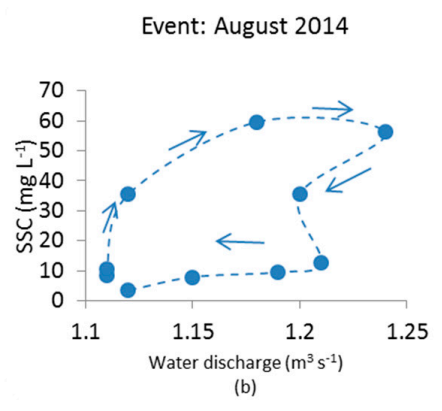

Event: July 2016

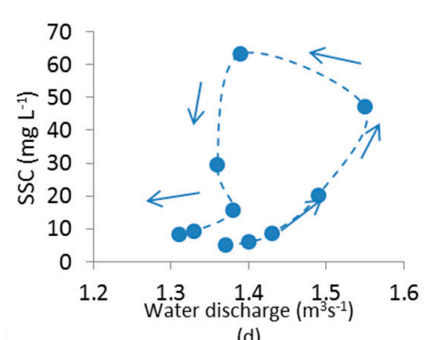

Figure 5. Typical hysteresis loops observed (daily averaged data) for summers of 2013 (a), 2014 (b), 2015 (c), and 2016 (d). 


\section{Discussion}

The SSC calculated from data recorded using a sentinel V-ADCP and an YSI 6136 turbidity probe using established calibration curves did not differ from a slope of 1 for the four studied years. Their relative high slopes and low y-intercepts of the best-fit regression lines indicated a good agreement between the two indirect measurement techniques of SSC [47]. However, the acoustic method provided generally lower values than optical method for high sediment concentrations. The difference may be due to a slight bias in the acoustic calibration for high of suspended sediment concentrations. There may also be variations of the particles size distribution for higher vs lower SSC. Moreover, the trend of SSC underestimation at smaller size distribution conditions by the acoustic method is often reported in the literature $[7,8,17]$. Ultimately, the results of this comparison reveal the potential of the acoustic backscatter technique for a non-intrusive monitoring of SSC within rivers with high sediment loads. Further investigations are needed for accuracy assessment of the outputs of the two measurement approaches by in situ automatic sampling during rainstorms events.

The correlation values for streamflow and water velocity increased with an increasing threshold for SSC. It appears therefore that high SSC are more associated with the river processes. Thus, this highlighted the important role of the water velocity in sediment transport capacity by the river during events. The sediment transport capacity also depends on the hydraulic and morphological characteristics of the river [48,49] and it may increase with the increasing of the flow rate [50]. By contrast, the impact of the variability of precipitation on SSC appears to be more complex and thorough investigations are needed to better understand sediment process patterns.

Frequent occurrence of clockwise SSC-flow hysteresis patterns was observed. A similar outcome has been reported in many previous studies and the rapid exhaustion of available sediments was pointed out as the principal cause of the clockwise hysteresis patterns [26,51,52]. Dunk River, as an important PEI alluvial river, the rapid sediment mobilization from land near riparian zone by intense rainstorms and from the bed river by high flow may potentially result in a clockwise hysteresis loop. There is an increase in turbulence and discharge within a river during rainstorm events. The high turbulence may result in high sediment concentration from resuspension of the bed sediments, followed by a gradually decrease of sediment delivery to the river during prolonged rainstorms [53-55]. The sediment concentration peaks occur before discharge peaks for clockwise hysteresis loops. The counter-clockwise hysteresis may be the result of late arrival of sediment at the point of measurement and the timing of the rainfall events or spatial location could explain waves of higher SSC arriving after the flow had started to decline [53-55]. The hysteresis loop pattern may be linked to the characteristics of the source sediment as well as to the frequency and intensity of precipitation $[24,56,57]$.

\section{Conclusions}

This study focused on the comparison of continual SSC monitoring by acoustic and optical approaches on the Dunk River and the characterization of sediment dynamic variation. The SSC calculated from data recorded using an ADCP and an OBS using established calibration curves showed good agreement between the two techniques. High SSC was more correlated to streamflow and water velocity than precipitation. The SSC-discharge relationship was dominated by clockwise hysteresis loops and it may be linked to the characteristics of the source sediment as well as to rainstorms behaviors for summer periods. Further investigations will be needed for better understanding of SSC dynamic during all periods of the year. For future work, a close analysis of temporal and spatial rainfall records, from a denser storm event sampling network would be useful to improve dynamic sediment characterization.

Author Contributions: Conceptualization: Z.S., A.S.-H., S.C.C., and M.R.v.d.H.; formal analysis: Z.S.; funding acquisition: A.S.-H.; investigation: Z.S.; methodology: Z.S., A.S.-H., S.C.C., and M.R.v.d.H.; supervision: A.S.-H., S.C.C., and M.R.v.d.H.; validation: A.S.-H., S.C.C., and M.R.v.d.H.; writing-original draft: Z.S.; writing-review and editing: A.S.-H., S.C.C., and M.R.v.d.H. 
Funding: This research was funded by the Canadian Water Network and the Department of Fisheries and Oceans Canada through support of Northumberland Strait Environmental Monitoring Partnership (NorSt-EMP) node of the Canadian Watershed Research Consortium and through the Scientific Director's Research Fund (SCC)

Acknowledgments: We owe thanks to Christina Pater for her assistance during field work.

Conflicts of Interest: The authors declare no conflict of interest. The funders had no role in the design of the study; in the collection, analyses, or interpretation of data; in the writing of the manuscript, or in the decision to publish the results.

\section{References}

1. Cunjak, R.A.; Newbury, R.W. 21-Atlantic Coast Rivers of Canada. In Rivers of North America; Benke, A.C., Cushing, C.E., Eds.; Academic Press: Burlington, VT, USA, 2005; pp. 938-980. [CrossRef]

2. Cloern, J.E.; Abreu, P.C.; Carstensen, J.; Chauvaud, L.; Elmgren, R.; Grall, J.; Greening, H.; Johansson, J.O.R.; Kahru, M.; Sherwood, E.T.; et al. Human activities and climate variability drive fast-paced change across the world's estuarine-coastal ecosystems. Glob. Chang. Biol. 2016, 22, 513-529. [CrossRef]

3. Boyd, C.E. Water Quality: An Introduction, 2nd ed.; Springer: New York, NY, USA, 2015.

4. Suedel, B.C.; Lutz, C.H.; Clarke, J.U.; Clarke, D.G. The effects of suspended sediment on walleye (Sander vitreus) eggs. J. Soils Sediments 2012, 12, 995-1003. [CrossRef]

5. Hudson, N. Soil Conservation: Fully Revised and Updated, 3rd ed.; New India Publishing Agency: New Delhi, India, 2015; 392p.

6. Pearce, D.; Barbier, E.; Markandya, A. Sustainable Development: Economics and Environment in the Third World; Routledge: London, UK, 2000.

7. Ghaffari, P.; Azizpour, J.; Noranian, M.; Chegini, V.; Tavakoli, V.; Shah-Hosseini, M. Estimating suspended sediment concentrations using a broadband ADCP in Mahshahr tidal channel. Ocean Sci. Discuss. 2011, 8, 1601-1630. [CrossRef]

8. Felix, D.; Albayrak, I.; Boes, R.M. Continuous measurement of suspended sediment concentration: Discussion of four techniques. Measurement 2016, 89, 44-47. [CrossRef]

9. Merten, G.H.; Capel, P.D.; Minella, J.P.G. Effects of suspended sediment concentration and grain size on three optical turbidity sensors. J. Soils. Sediments 2014, 14, 1235-1241. [CrossRef]

10. Simmons, S.M.; Parsons, D.R.; Best, J.L.; Oberg, K.A.; Czuba, J.A.; Keevil, G.M. An evaluation of the use of a multibeam echo-sounder for observations of suspended sediment. Appl. Acoust. 2017, 126, 81-90. [CrossRef]

11. Sahin, C.; Verney, R.; Sheremet, A.; Voulgaris, G. Acoustic backscatter by suspended cohesive sediments: Field observations, Seine Estuary, France. Cont. Shelf. Res. 2017, 134, 39-51. [CrossRef]

12. Moura, M.G.; Quaresma, V.S.; Bastos, A.C.; Veronez, P. Field observations of SPM using ADV, ADP, and OBS in a shallow estuarine system with low SPM concentration-Vitória Bay, SE Brazil. Ocean Dyn. 2011, 61, 273-283. [CrossRef]

13. Zhang, W.-X.; Luo, X.-x.; Yang, S.-1. Comparison between measurements of suspended sediment concentration using ADP and OBS. J. Sediment Res. 2010, 5, 59-65.

14. Wei, X.; Wang, Y.; Yang, Y.; Chen, J.; Gao, J.; Wang, A.; Li, D.; Hu, G. Suspended sediment concentration in shallow sea: Comparative study of methods. Mar. Geol. Quat. Geol. 2013, 1, 161-170. [CrossRef]

15. Guerrero, M.; Di Federico, V. Suspended sediment assessment by combining sound attenuation and backscatter measurements-analytical method and experimental validation. Adv. Water Resour. 2018, 113, 167-179. [CrossRef]

16. Alberto, A.; St-Hilaire, A.; Courtenay, S.C.; van den Heuvel, M.R. Monitoring stream sediment loads in response to agriculture in Prince Edward Island, Canada. Environ. Monit. Assess. 2016, 188, 415. [CrossRef]

17. Guerrero, M.; Rüther, N.; Haun, S.; Baranya, S. A combined use of acoustic and optical devices to investigate suspended sediment in rivers. Adv. Water Resour. 2017, 102, 1-12. [CrossRef]

18. Hoitink, A.J.F.; Hoekstra, P. Observations of suspended sediment from ADCP and OBS measurements in a mud-dominated environment. Coastal Eng. 2005, 52, 103-118. [CrossRef]

19. Marttila, H.; Postila, H.; Kløve, B. Calibration of turbidity meter and acoustic doppler velocimetry (Triton-ADV) for sediment types present in drained peatland headwaters: Focus on particulate organic peat. River Res. Appl. 2010, 26, 1019-1035. [CrossRef] 
20. Moore, S.A.; Le Coz, J.; Hurther, D.; Paquier, A. On the application of horizontal ADCPs to suspended sediment transport surveys in rivers. Cont. Shelf. Res. 2012, 46, 50-63. [CrossRef]

21. Aich, V.; Zimmermann, A.; Elsenbeer, H. Quantification and interpretation of suspended-sediment discharge hysteresis patterns: How much data do we need? Catena 2014, 122, 120-129. [CrossRef]

22. Fan, X.; Shi, C.; Shao, W.; Zhou, Y. The suspended sediment dynamics in the Inner-Mongolia reaches of the upper Yellow River. Catena 2013, 109, 72-82. [CrossRef]

23. Marttila, H.; Kløve, B. Dynamics of erosion and suspended sediment transport from drained peatland forestry. J. Hydrol. 2010, 388, 414-425. [CrossRef]

24. Keesstra, S.D.; Davis, J.; Masselink, R.H.; Casalí, J.; Peeters, E.T.H.M.; Dijksma, R. Coupling hysteresis analysis with sediment and hydrological connectivity in three agricultural catchments in Navarre, Spain. J. Soils Sediments 2019, 19, 1598-1612. [CrossRef]

25. Gellis, A.C.; Mukundan, R. Watershed sediment source identification: Tools, approaches, and case studies. J. Soils Sediments 2013, 13, 1655-1657. [CrossRef]

26. Vercruysse, K.; Grabowski, R.C.; Rickson, R.J. Suspended sediment transport dynamics in rivers: Multi-scale drivers of temporal variation. Earth Sci. Rev. 2017, 166, 38-52. [CrossRef]

27. Pietroń, J.; Jarsjö, J.; Romanchenko, A.O.; Chalov, S.R. Model analyses of the contribution of in-channel processes to sediment concentration hysteresis loops. J. Hydrol. 2015, 527, 576-589. [CrossRef]

28. Eder, A.; Strauss, P.; Krueger, T.; Quinton, J.N. Comparative calculation of suspended sediment loads with respect to hysteresis effects (in the Petzenkirchen catchment, Austria). J. Hydrol. 2010, 389, 168-176. [CrossRef]

29. Coffin, M.R.; Courtenay, S.C.; Pater, C.C.; van den Heuvel, M.R. An empirical model using dissolved oxygen as an indicator for eutrophication at a regional scale. Mar. Pollut. Bull. 2018, 133, 261-270. [CrossRef]

30. Commission on Land and Local Governance. Report of Commission on Land and Local Governance; Communications PEI-Document Publishing Centre: Charlottetown, PEI, Canada, 2009.

31. PEI Department of Fisheries and Environment. Water on Prince Edward Island: Understanding the Resource, Knowing the Issues; PEI Department of Fisheries and Environment; Environment Canada: Charlottetown, PEI, Canada, 1996.

32. Xing, Z.; Chow, L.; Cook, A.; Benoy, G.; Rees, H.; Ernst, B.; Meng, F.; Li, S.; Zha, T.; Murphy, C.; et al. Pesticide Application and Detection in Variable Agricultural Intensity Watersheds and Their River Systems in the Maritime Region of Canada. Arch. Environ. Contam. Toxicol. 2012, 63, 471-483. [CrossRef] [PubMed]

33. Hellou, J.; Cook, A.; Ernst, B.; Leonard, J.; Steller, S. Pesticides in an estuary on Prince Edward Island, Canada. Environment Canada, Atlantic Region, Occasional Report 23. In Proceedings of the 6th Bay of Fundy Ecosystem Partnership Workshop, Cornwallis, NS, Canada, 29 September-2 October 2004; pp. 425-429.

34. Sirabahenda, Z.; St-Hilaire, A.; Courtenay, S.C.; Alberto, A.; van den Heuvel, M.R. A modelling approach for estimating suspended sediment concentrations for multiple rivers influenced by agriculture. Hydrol. Sci. J. 2017, 62, 2209-2221. [CrossRef]

35. Van de Poll, H. Lithostratigraphy of the Prince Edward Island redbeds. Atlantic Geol. 1989, $25,23-35$. [CrossRef]

36. Omar, A.F.B.; Matjafri, M.Z.B. Turbidimeter design and analysis: A review on optical fiber sensors for the measurement of water turbidity. Sensors 2009, 9, 8311-8335. [CrossRef] [PubMed]

37. Pavey, B.; Saint-Hilaire, A.; Courtenay, S.; Ouarda, T.; Bobée, B. Exploratory study of suspended sediment concentrations downstream of harvested peat bogs. Environ. Monit. Assess. 2007, 135, 369-382. [CrossRef]

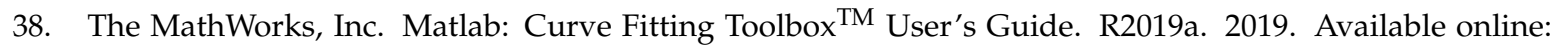
https://www.mathworks.com/help/pdf_doc/curvefit/curvefit.pdf (accessed on 10 April 2019).

39. Gartner, J.W. Estimating suspended solids concentrations from backscatter intensity measured by acoustic Doppler current profiler in San Francisco Bay, California. Mar. Geol. 2004, 211, 169-187. [CrossRef]

40. Deines, K.L. Backscatter estimation using Broadband acoustic Doppler current profilers. In Proceedings of the IEEE Sixth Working Conference on Current Measurement (Cat. No.99CH36331), San Diego, CA, USA, 13-13 March 1999; pp. 249-253.

41. Mullison, J. Backscatter Estimation Using Broadband Acoustic Doppler Current Profilers-Updated. In Proceedings of the ASCE Hydraulic Measurements \& Experimental Methods Conference, Durham, NH, USA, 9-12 July 2017. 
42. Moriasi, D.N.; Arnold, J.G.; Van Liew, M.W.; Bingner, R.L.; Harmel, R.D.; Veith, T.L. Model Evaluation Guidelines for Systematic Quantification of Accuracy in Watershed Simulations. Trans. ASABE 2007, $50,885$. [CrossRef]

43. Nash, J.E.; Sutcliffe, J.V. River flow forecasting through conceptual models part I-A discussion of principles. J. Hydrol. 1970, 10, 282-290. [CrossRef]

44. Gupta, H.V.; Sorooshian, S.; Yapo, P.O. Status of Automatic Calibration for Hydrologic Models: Comparison with Multilevel Expert Calibration. J. Hydrol. Eng. 1999, 4, 135-143. [CrossRef]

45. Hauke, J.; Kossowski, T. Comparison of Values of Pearson's and Spearman's Correlation Coefficients on the Same Sets of Data. Quaest. Geogr. 2011, 30, 87. [CrossRef]

46. Kendall, M.G. A new measure of rank correlation. Biometrika 1938, 30, 81-93. [CrossRef]

47. Willmott, C.J. On the validation of models. Phys. Geogr. 1981, 2, 184-194. [CrossRef]

48. Wu, B.; Wang, Z.; Shen, N.; Wang, S. Modelling sediment transport capacity of rill flow for loess sediments on steep slopes. Catena 2016, 147, 453-462. [CrossRef]

49. Tena, A.; Vericat, D.; Batalla, R.J. Suspended sediment dynamics during flushing flows in a large impounded river (the lower River Ebro). J. Soils Sediments 2014, 14, 2057-2069. [CrossRef]

50. Yang, S.-Q. Sediment transport capacity in rivers. J. Hydraul. Res. 2005, 43, 131-138. [CrossRef]

51. Sun, L.; Yan, M.; Cai, Q.; Fang, H. Suspended sediment dynamics at different time scales in the Loushui River, south-central China. Catena 2016, 136, 152-161. [CrossRef]

52. Fang, N.F.; Shi, Z.H.; Chen, F.X.; Zhang, H.Y.; Wang, Y.X. Discharge and suspended sediment patterns in a small mountainous watershed with widely distributed rock fragments. J. Hydrol. 2015, 528, 238-248. [CrossRef]

53. Zhang, Q.; Harman, C.J.; Ball, W.P. An improved method for interpretation of riverine concentration-discharge relationships indicates long-term shifts in reservoir sediment trapping. Geophys. Res. Lett. 2016, 43, 10-215. [CrossRef]

54. Chanat, J.G.; Rice, K.C.; Hornberger, G.M. Consistency of patterns in concentration-discharge plots. Water Resour. Res. 2002, 38, 22-1-22-10. [CrossRef]

55. Warrick, J.A. Trend analyses with river sediment rating curves. Hydrol. Process. 2015, 29, 936-949. [CrossRef]

56. Zimmermann, A.; Francke, T.; Elsenbeer, H. Forests and erosion: Insights from a study of suspended-sediment dynamics in an overland flow-prone rainforest catchment. J. Hydrol. 2012, 428-429, 170-181. [CrossRef]

57. De Girolamo, A.M.; Pappagallo, G.; Lo Porto, A. Temporal variability of suspended sediment transport and rating curves in a Mediterranean river basin: The Celone (SE Italy). Catena 2015, 128, 135-143. [CrossRef] 